\title{
Article \\ Structure-Activity Relationship of the Thiacalix[4]arenes Family with Sulfobetaine Fragments: Self-Assembly and Cytotoxic Effect against Cancer Cell Lines
}

\author{
Luidmila Yakimova ${ }^{1, * \mathbb{D}}$, Aisylu Kunafina ${ }^{1}$, Aigul Nugmanova ${ }^{1}$, Pavel Padnya ${ }^{1} \mathbb{D}$, Alexandra Voloshina ${ }^{2}$, \\ Konstantin Petrov ${ }^{2}$ and Ivan Stoikov ${ }^{1, *(D)}$
}

check for

updates

Citation: Yakimova, L.; Kunafina, A.; Nugmanova, A.; Padnya, P.;

Voloshina, A.; Petrov, K.; Stoikov, I. Structure-Activity Relationship of the Thiacalix[4]arenes Family with Sulfobetaine Fragments: Self-

Assembly and Cytotoxic Effect against Cancer Cell Lines. Molecules 2022, 27, 1364. https://doi.org/ $10.3390 /$ molecules 27041364

Academic Editor: Vladimir Burilov

Received: 26 January 2022

Accepted: 14 February 2022

Published: 17 February 2022

Publisher's Note: MDPI stays neutral with regard to jurisdictional claims in published maps and institutional affiliations.

Copyright: (C) 2022 by the authors. Licensee MDPI, Basel, Switzerland. This article is an open access article distributed under the terms and conditions of the Creative Commons Attribution (CC BY) license (https:// creativecommons.org/licenses/by/ $4.0 /)$
1 A.M. Butlerov' Chemistry Institute, Kazan Federal University, 18 Kremlevskaya Street, 420008 Kazan, Russia; ais.kunaf@yandex.ru (A.K.); aygul9pul9@mail.ru (A.N.); padnya.ksu@gmail.com (P.P.)

2 Arbuzov Institute of Organic and Physical Chemistry, FRC Kazan Scientific Center of RAS, 8 Arbuzov Street, 420088 Kazan, Russia; microbi@iopc.ru (A.V.); kpetrov2005@mail.ru (K.P.)

* Correspondence: mila.yakimova@mail.ru (L.Y.); ivan.stoikov@mail.ru (I.S.); Tel.: +7-843-233-7241 (I.S.)

\begin{abstract}
Regulating the structure of macrocyclic host molecules and supramolecular assemblies is crucial because the structure-activity relationship often plays a role in governing the properties of these systems. Herein, we propose and develop an approach to the synthesis of the family of sulfobetaine functionalized thiacalix[4]arenes with regulation of the self-assembly and cytotoxic effect against cancer cell lines. The dynamic light scattering method showed that the synthesized macrocycles in cone, partial cone and 1,3-alternate conformations form submicron-sized particles with $\mathrm{Ag}^{+}$in water, but the particle size and polydispersity of the systems studied depend on the macrocycle conformation. Based on the results obtained by ${ }^{1} \mathrm{H}$ and ${ }^{1} \mathrm{H}-{ }^{1} \mathrm{H}$ NOESY NMR spectroscopy and transmission electron microscopy for the macrocycles and their aggregates with $\mathrm{Ag}^{+}$, a coordination scheme for the $\mathrm{Ag}^{+}$and different conformations of $p$-tert-butylthiacalix[4]arene functionalized with sulfobetaine fragments was proposed. The type of coordination determines the different shapes of the associates. Cytotoxic properties are shown to be controlled by the shape of associates, with the highest activity demonstrated by thiacalix[4]arenes in partial cone conformation. This complex partial cone $/ \mathrm{Ag}^{+}$is two times higher than the reference drug imatinib mesylate. High selectivity against cervical carcinoma cell line indicates the prospect of their using as components of new anticancer system.
\end{abstract}

Keywords: sulfobetaines; thiacalixarene; self-assembly; silver ions; cytotoxicity; cancer cell lines

\section{Introduction}

Multiple drug resistance (MDR) is a growing public health concern worldwide [1-5]. The main challenge faced by many researchers is the resistance to cancer and various bacterial and viral infections. It leads to the ineffectiveness of therapy. It is now well established that inappropriate use of antimicrobial, antiviral, anticancer agents or use of ineffective dosage forms [6], as well as premature termination of treatment can lead to the development of drug resistances [7]. MDR is not limited to bacterial infections; this phenomenon is also characteristic of mycoses. Interestingly, cancer cells are drug resistant too $[8,9]$. Moreover, cancer cells can be compared to superbugs since almost $50 \%$ of cancer cells do not respond to any anticancer drugs [10]. Existing research recognizes that any drug effects both on cancer and on healthy cells [11].

The clinical development portfolio of new antimicrobial drugs is extremely small. In 2019, the World Health Organization (WHO) identified 32 antibiotics that are in clinical development and are intended to treat pathogens included in the WHO list of priority pathogens. Only six antibiotics are classified as innovative [12]. In addition, the lack of availability of quality antimicrobial drugs remains a major problem. 
Several approaches to solving the problem of MRD have been proposed. One of the most widely used approaches is the use of innovative delivery systems (liposomes, nanofibers, lipid particles, etc.) for the encapsulation (solubilization) of drugs existing on the world market. The bac/virus resistance issue will be solved by developing new methods for the delivery of existing drugs rather than by synthesizing new medicines. Thus, the effect of several antibiotics, encapsulated directly in nanofibers, was tested on laboratory cultures of various microbes [13]. Antibiotics have proven extremely effective against a variety of pathogenic bacteria and fungi, including Escherichia coli and Pseudomonas aeruginosa, two of the most drug-resistant organisms. The packaging of antibacterial substances in dosage forms makes the action of drugs more targeted. New dosage forms remain effective for a longer period than with the usual method of their delivery.

The second approach is the development of nanostructures without the participation of a drug through the laws and approaches of supramolecular chemistry [14]. This direction can become the basis for the creation of a new class of anticancer systems ("nano anticancer drug") with controlled activity, selectivity, and biological compatibility. Among inorganic nanoparticles, both $\mathrm{Ag}$ nanoparticles [15] and $\mathrm{Ag}^{+}[16,17]$ cations are the most widely used, for which a pronounced ability to inactivate viruses, smallpox and influenza A-1, B has been shown $[18,19]$. They are active against some enteroviruses, adenoviruses and human immunodeficiency virus. Moreover, it has been shown that the toxicity of both $\mathrm{Ag}^{+}$ions and Ag nanoparticles is quite high [20]. Ag nanoparticles can be toxic due to their small size; on the other hand, $\mathrm{Ag}$ nanoparticles can be toxic because they release $\mathrm{Ag}^{+}$, which are well known for their antibacterial and destructive effects on cell membranes [21,22]. Therefore, the regulation of the cytotoxic effect of $\mathrm{Ag}^{+}$on normal and tumor cell cultures is undoubtedly a non-trivial task.

In this regard, the development of new approaches of supramolecular chemistry and the identification of the structure-activity relationship is an important and promising problem [23,24]. Macrocyclic platforms-thiacalix[4]arenes, can be used for the synthesis of compounds with a regulated ability to self-assembly [25-27]. Due to the ability to fix the macrocyclic ring in several conformations and the relative ease of its functionalization, functional groups can be arranged in a predetermined manner in space. It determines the tendency to self-assembly into nanostructures under the influence of the substrate (ions, molecules) [28-30].

In this work, we synthesize sulfobetaine derivatives of thiacalix[4]arene in three conformations using the "template" synthesis method (with alkali metal ions as a template) to create multivalent structures. In the presence of $\mathrm{Ag}^{+}$, these derivatives are capable to self-assemble into associates with different architectures (shapes) and, as a consequence, with cytotoxic selectivity for the cervical carcinoma cell line.

\section{Results and Discussion}

\subsection{Synthesis of Compounds 3-5}

In our previous work, we synthesized derivatives of $p$-tert-butylthiacalix[4]arene with sulfobetaine moieties on the lower rim in cone conformation and studied their capability of self-assembling in the presence of Ag (I) [31]. Due to the presence of sulfide bridges in the thiacalix[4]arene, the conformational mobility of the macrocyclic ring increases, which facilitates the preparation of two additional conformers (partial cone and 1,3-alternate) [32]. In this case, the arrangement of substituents at phenolic oxygen in space is different for all stereoisomers, which makes it possible to organize an orientation of the binding sites that is individual for each conformer, and this will undoubtedly lead to selectivity of interaction with the substrate. In this regard, in order to evaluate the effect of the conformation of the macrocyclic platform on self-assembly with $\mathrm{Ag}$ (I) cations, we synthesized three conformers (cone, partial cone and 1,3-alternate) of thiacalix[4]arene containing four sulfobetaine fragments (3-5) (Scheme 1). Aminolysis of $p$-tert-butylthiacalix[4]arenes tetrasubstituted at the lower rim by ester fragments in cone (1-cone), partial cone (1-paco) and 1,3-alternate (1-alt) conformation by $\mathrm{N}, \mathrm{N}$-dimethylpropane-1,3-diamine give the tetrasubstituted thia- 
calix[4]arene derivatives containing tertiary amino groups (2-cone, 2-paco, 2-alt) [33]-the precursors for the synthesis of sulfobetaine macrocyclic compounds.
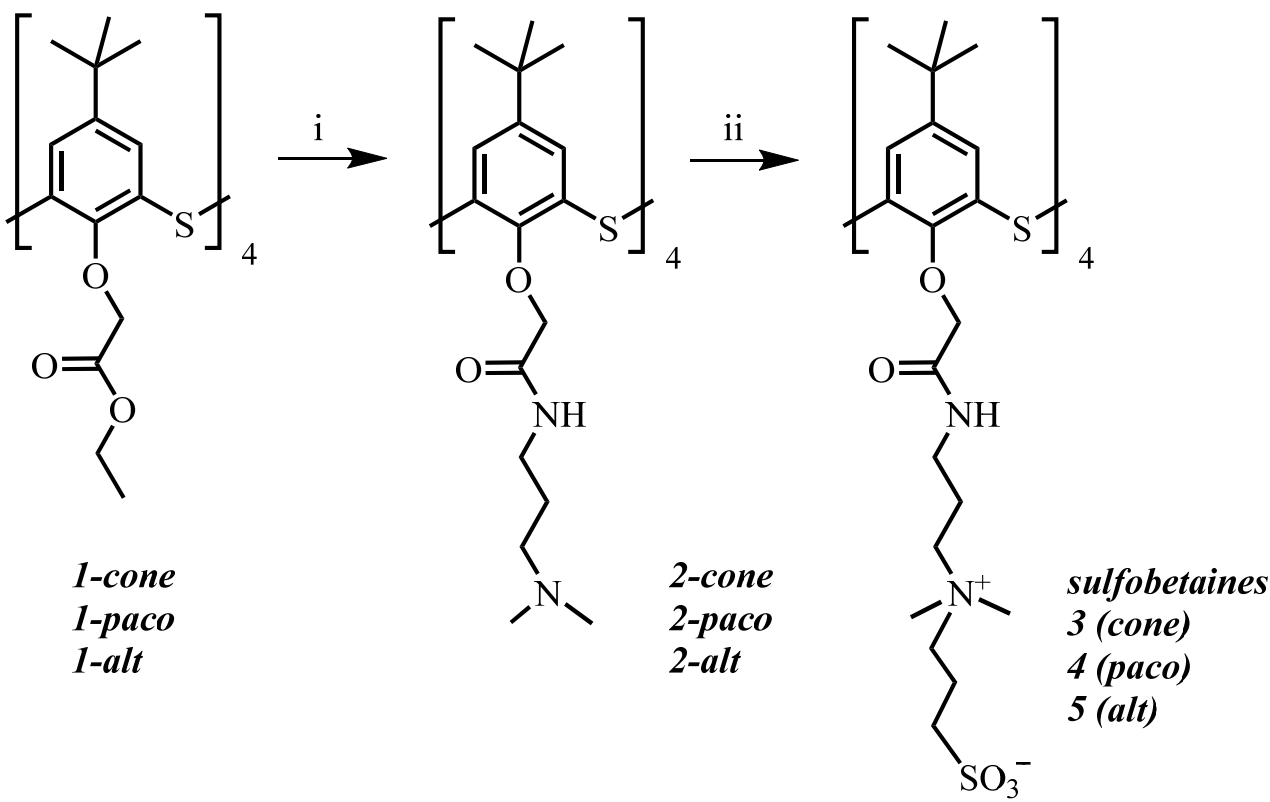

Scheme 1. Reagents and conditions: $\mathrm{i}-\mathrm{N}, \mathrm{N}$-dimethylpropane-1,3-diamine, $\mathrm{C}_{6} \mathrm{H}_{5} \mathrm{CH}_{3} / \mathrm{CH}_{3} \mathrm{OH}$, reflux; ii-1,3-propanesultone, $\mathrm{CH}_{3} \mathrm{CN}$, reflux.

Next, the reactions of compounds 2 in cone, partial cone and 1,3-alternate conformations in acetonitrile with 1,3-propanesultone were attempted for $72 \mathrm{~h}$. The reactions with 1,3propanesultone gave products 3-5 in a yields of 79, 95 and $91 \%$. The complete set of ${ }^{1} \mathrm{H}$, ${ }^{13} \mathrm{C}$ NMR and IR spectroscopy and ESI mass spectrometry data confirm the formation of the tetrasubstituted products 3-5 (Figures S1-S12, see details in Supplementary Materials).

\subsection{Self-Assembly of Water-Soluble Sulfobetaines 3-5}

With the sulfobetaine macrocycles 3-5 in hand, we investigated their aggregation in water (Figures S13-S42, ESI). Colloidal solutions of macrocycles 3-5 were characterized by a high value of dispersity (PDI $=0.31-0.91$ ) and particle size from 317 to $421 \mathrm{~nm}$ (Tables $\mathrm{S} 1-\mathrm{S} 3)$. In the range of concentrations studied for sulfobetaine 3 in cone conformation, the aggregate size decreases (from 421 to $317 \mathrm{~nm}$ ) with a lowering concentration $(1 \times$ $10^{-4}-1 \times 10^{-6} \mathrm{M}$ ), while the dispersity also decreases (Table S1). After the addition of $\mathrm{AgNO}_{3}$ at a 1:1 molar ratio $\left(3: \mathrm{Ag}^{+}\right)$, nanosized particles with a hydrodynamic diameter of about $168 \mathrm{~nm}$ and a low dispersity $(\mathrm{PDI}=0.17)$ were formed. At the same time, with a decrease in the concentration of $\mathbf{3}$, an opposite tendency is observed (Table S1). Obviously, with a higher macrocycle concentration, some charge compensation occurs, which causes higher monodispersity.

Sulfobetaine 5 in 1,3-alternate conformation in all systems, at various concentrations of Ag (I), was not capable of forming stable monodisperse systems (Table S3). In the concentration range studied $\left(1 \times 10^{-4}-1 \times 10^{-6} \mathrm{M}\right)$, there is no definite trend in the size change, while the dispersity increases (from 0.38 to 0.91 ) with a lowering concentration (Table S3). The addition of Ag (I) to the solution of 5 in stoichiometric ratios 1:1, 1:4, 1:10 did not lead to the formation of a system with a monomodal distribution. Therefore, both the aggregate size formed by macrocycle 5 and their dispersity weakly depend on the concentration.

A more complicated picture was observed for sulfobetaine 4 in partial cone conformation. In the concentration studied $\left(1 \times 10^{-4} \mathrm{M}\right)$, macrocycle 4 forms monodisperse systems at all the ratios studied with $\mathrm{Ag}$ (I) with a size of 123-187 nm (Table S2). Dilution of the system to $1 \times 10^{-5} \mathrm{M}$ led to a violation of the stability of the system and, as a 
consequence, to an increase in the polydispersity and size of the resulting aggregates. At a lower concentration $\left(1 \times 10^{-6} \mathrm{M}\right)$, no associates were found.

Note that $\mathrm{Ag}(\mathrm{I})$, rather than the reduced form of $\operatorname{Ag}(0)$, participates in the formation of aggregates with macrocycles 3-5. This is confirmed by the UV spectra of the studied systems, which were recorded after 1 day, 3 days, and 7 days. The spectra lack the absorption band of reduced silver at $430 \mathrm{~nm}$ (Figures S43-S45).

The formation of associates in the presence of $\mathrm{Ag}^{+}$was also recorded in the solid phase by TEM (Figure 1). The shape of the associates formed by macrocycles 3 and 4 is different. In the case of associates $3 / \mathrm{Ag}^{+}$, spherical particles are formed, while the association of macrocycle 4 with $\mathrm{Ag}^{+}$gives associates of an extended shape.

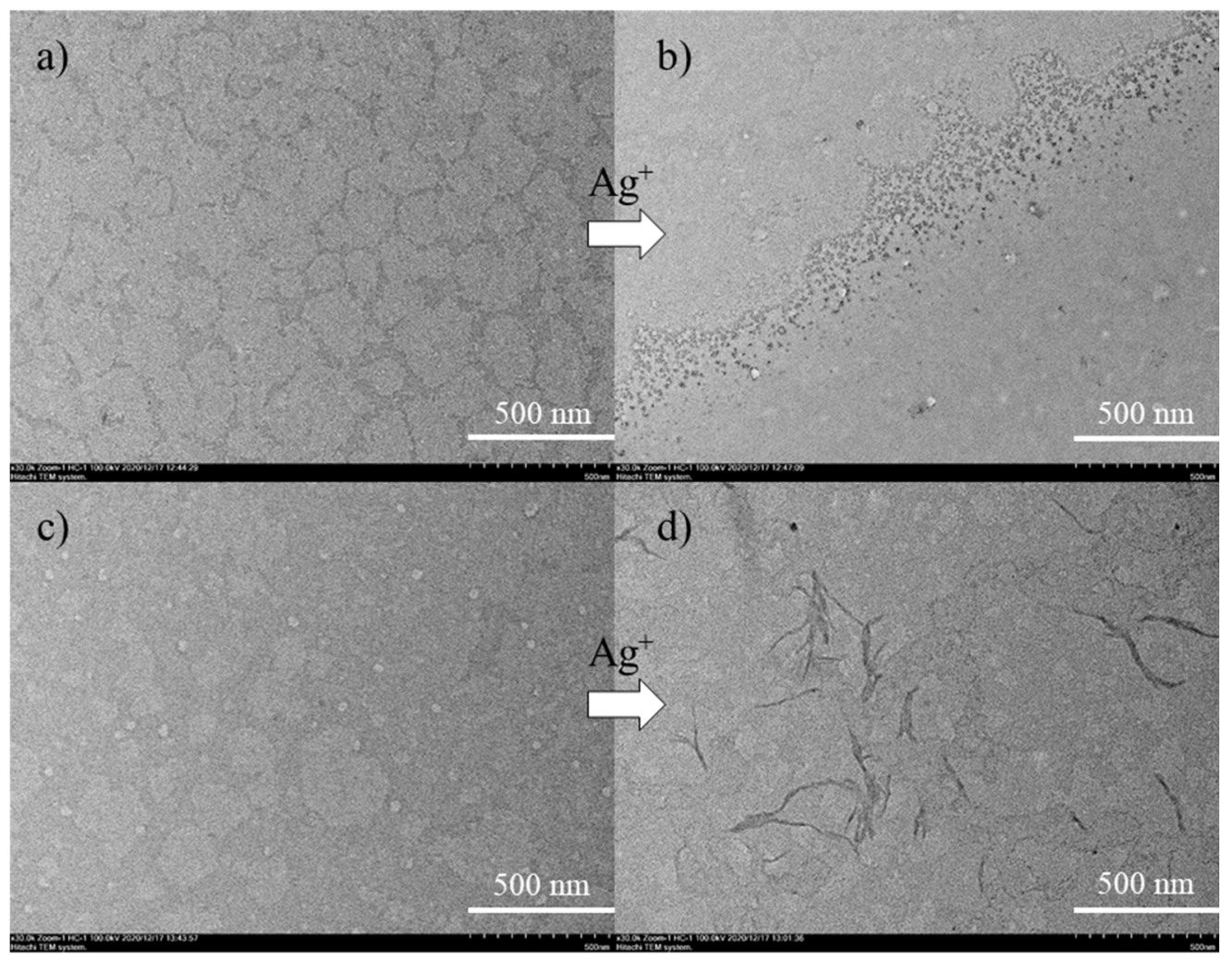

Figure 1. TEM images of (a) 3, (b) $3 / \mathrm{Ag}^{+}$, (c) 4 and (d) $4 / \mathrm{Ag}^{+}$associates (1:4 molar ratio) in water $\left(1 \times 10^{-4} \mathrm{M}\right)$.

Obviously, such a difference in the shape of associates is due to the structure of the macrocycle, namely, to the different arrangement of substituents relative to the macrocyclic cavity (cone, partial cone and 1,3-alternate). To confirm our assumption, we studied the systems of macrocycles 3-5 and their associates with $\mathrm{Ag}^{+}$by ${ }^{1} \mathrm{H}$ NMR spectroscopy (Figure 2, Figures S46 and S47).

Unfortunately, no significant changes in the ${ }^{1} \mathrm{H}$ NMR spectrum for the $\mathbf{3} / \mathrm{Ag}^{+}$system were found (Figure S46). We used the 2D 1H,1H-nuclear Overhauser effect spectroscopy (NOESY) NMR method (Figures S48 and S49) to confirm the formation and structure of associates. There are observed cross-peak between the methylene protons of $\mathrm{CH}_{2} \mathrm{SO}_{3}{ }^{-}$ and the methyl protons of $\mathrm{Me}_{2} \mathrm{~N}^{+}$of sulfobetaine fragment $1 \mathrm{H}, 1 \mathrm{H}-\mathrm{NOESY} \mathrm{NMR} \mathrm{spectrum}$. The presence of these cross peaks indicates a spatially close location of $\mathrm{CH}_{2} \mathrm{SO}_{3}{ }^{-}$and the methyl protons of $\mathrm{Me}_{2} \mathrm{~N}^{+}$in sulfobetaine fragments of pillar[5]arenes 3. Due to electrostatic interactions, the charge in the sulfobetaine part is compensated, and a stable six-membered ring is formed (Figure 2). The coordination of $\mathrm{Ag}^{+}$is possible with bridging sulfur atoms and at the oxygen atoms of the carbonyl groups of the receptor [34,35]. Apparently, such an organization of the sulfobetaine fragment in the symmetric cone conformation in 
space and the coordination of $\mathrm{Ag}^{+}$over bridging sulfur atoms does not lead to significant shielding of the macrocycle fragments. This is not reflected in the ${ }^{1} \mathrm{H}$ NMR spectrum of the $3 / \mathrm{Ag}^{+}$associates.
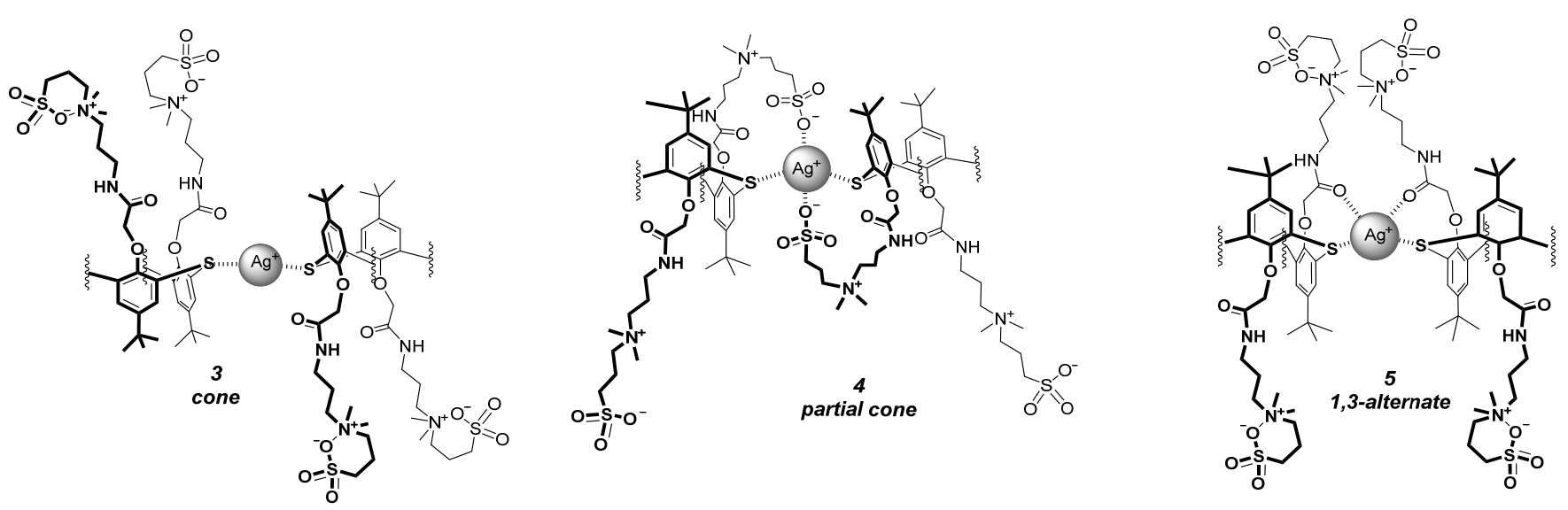

Figure 2. Coordination of the metals by the isomers of thiacalix[4]arenes $\mathbf{3}-\mathbf{5}$ proposed for various conformations.

In the ${ }^{1} \mathrm{H}$ NMR spectrum of $5 / \mathrm{Ag}^{+}$associates formed by a macrocycle in the $1,3-$ alternate conformation, significant changes were found only in the region of oxymethylene protons. The signal shifts to the low-field region by $0.16 \mathrm{ppm}$ (Figure S47). At the same time, in the ${ }^{1} \mathrm{H}-{ }^{1} \mathrm{H}$ NOESY NMR spectrum of macrocycle 5 , a cross-peak between the methylene group of $\mathrm{CH}_{2} \mathrm{SO}_{3}{ }^{-}$and the methyl groups of $\mathrm{Me}_{2} \mathrm{~N}^{+}$is also observed (Figure S52), which indicates the formation of a cyclic structure between the charged groups of the sulfobetaine fragment. In this case, the $\mathrm{Ag}^{+}$is so oriented in the space of the symmetric conformation of the macrocycle that it causes shielding of only oxymethylene fragments of $\mathrm{OCH}_{2}$ and does not promote self-assembly into ordered aggregates of the same size (Figure S47). This is possible only in the case of a similar arrangement of the $\mathrm{Ag}^{+}$cation, as shown in the Figure 2.

The most significant changes in the ${ }^{1} \mathrm{H}$ NMR spectrum are observed for the $4 / \mathrm{Ag}^{+}$system (Figure 3). Macrocycle 4 in paco conformation is more dissymmetric than macrocycles in cone and 1,3-alternate conformations and is more conformationally labile. Proton signal shifts are observed for almost all fragments, except for the tert-butyl groups of the aromatic ring and methyl groups at the quaternized nitrogen atom. The greatest changes were observed for aromatic protons, as well as methylene protons of sulfobetaine fragments.

It should be noted that in the ${ }^{1} \mathrm{H}-{ }^{1} \mathrm{H}$ NOESY NMR spectrum of macrocycle 4 , in contrast to macrocycles 3 and 5 , there are no cross peaks between the methylene group of $\mathrm{CH}_{2} \mathrm{SO}_{3}{ }^{-}$and the methyl groups of $\mathrm{Me}_{2} \mathrm{~N}^{+}$(Figure S50). This means that the conformational lability of macrocycle 4 increases the mobility of the fragments relative to the macrocyclic ring. This complicates such an orientation of groups in space, which would lead to intermolecular cyclization of the sulfobetaine fragment. As a result, coordination of the $\mathrm{Ag}^{+}$cation becomes possible not only at bridging sulfur atoms and oxygen atoms of carbonyl groups but also through electrostatic interactions with the sulfo group of the betaine fragment (Figure 2). Such electrostatic interactions "glue" the thiacalix[4]arene molecules into extended structures, which we observe in the images obtained by the method of transmission electron spectroscopy (Figure 1). The coordination of $\mathrm{Ag}^{+}$for different conformations of $p$-tert-butylthiacalix[4]arene functionalized with sulfobetaine fragments is schematically shown in Figure 4. 

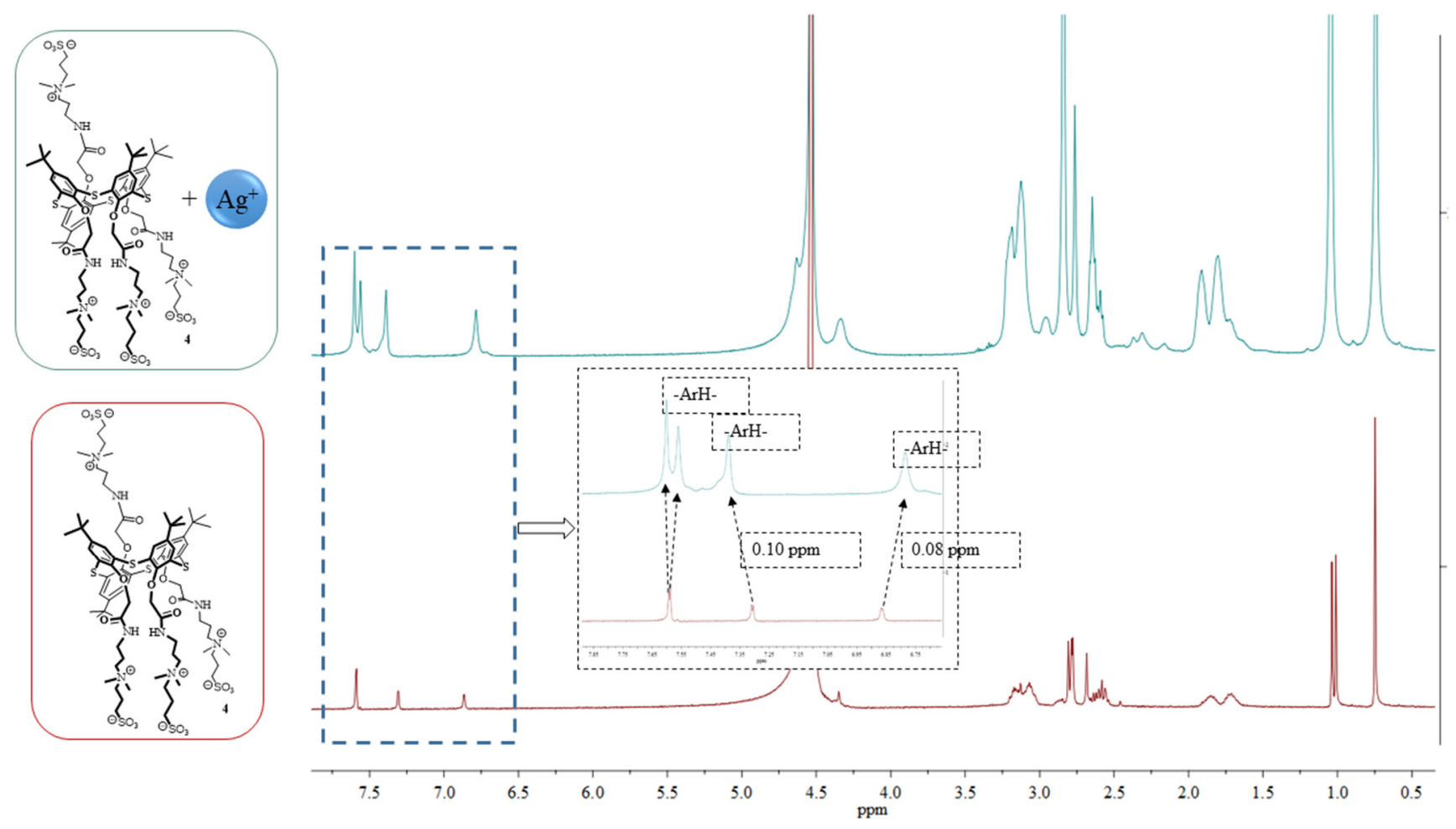

Figure 3. ${ }^{1} \mathrm{H}$ NMR spectra of macrocycle $4\left(1 \times 10^{-3} \mathrm{M}\right)$ and associates $4 / \mathrm{Ag}^{+}$at a ratio of 1:4 in $\mathrm{D}_{2} \mathrm{O}$ at $298 \mathrm{~K}$.
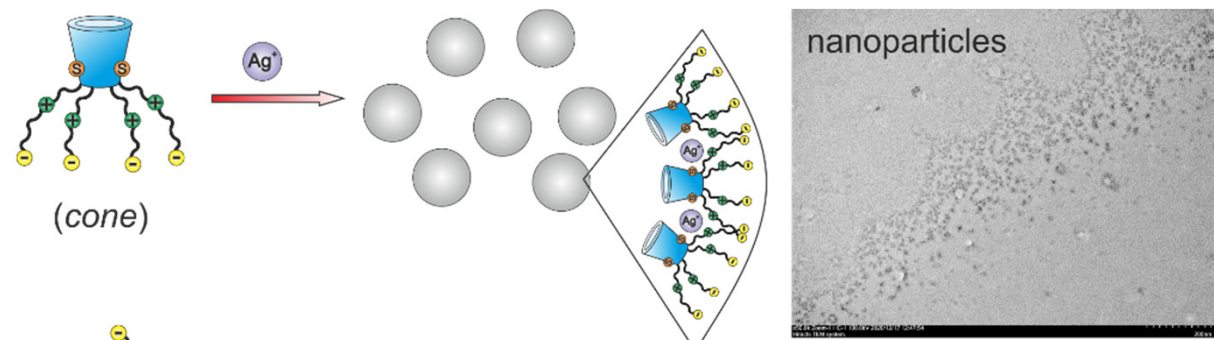

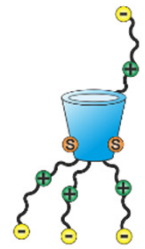

(partial cone)
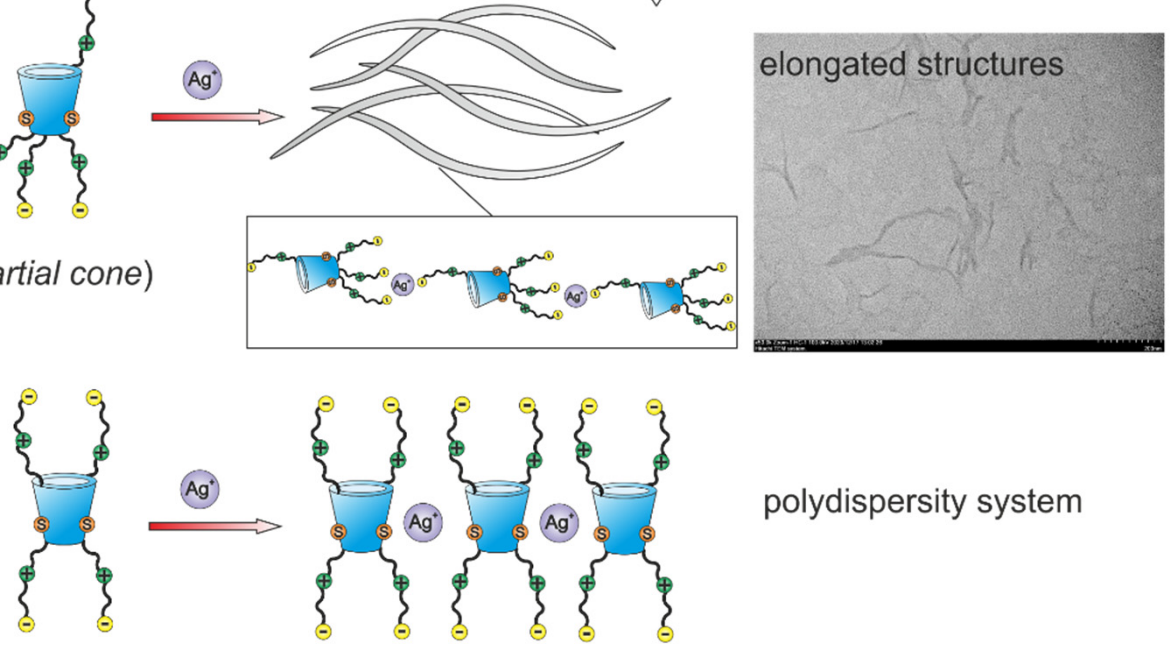

(1,3-alternate) polydispersity system

Figure 4. The possible structures of $p$-tert-butyl thiacalix[4]arenes 3-5 aggregated with $\mathrm{Ag}^{+}$cations. 


\subsection{Cytotoxicity of Test Compounds 3-5 on Cancer and Non-Cancer Human Cell Lines}

It is known that Ag nanoparticles are highly cytotoxic [20]. It is worth noting that $\mathrm{Ag}$ nanoparticles can be toxic because they release $\mathrm{Ag}^{+}$, which are well known for their antibacterial and other destructive behavior [36]. Moreover, nanoparticles enhance the effect of ions $[37,38]$. Taking these data into account, the cytotoxicity of the synthesized nanostructures based on sulfobetaine thiacalix[4]arenes and $\mathrm{Ag}^{+}$, as the most aggressive form of silver, was evaluated. We studied the cytotoxic effect of thiacalix[4]arene derivatives 3-5 and their aggregates $3 / \mathrm{Ag}^{+}$and $4 / \mathrm{Ag}^{+}$on cancer human cell lines MCF-7, M-HeLa, HuTu 80 and on non-cancer cells (change liver) in the concentration range of $1-100 \mu \mathrm{M}$. This concentration range is recommended for screening for new anticancer agents (1-100 $\mu \mathrm{M})$ [39].

It was shown that compounds 3-5 do not demonstrate cytotoxic activity against all cell lines (Table 1). It can be seen that among the tested compounds, the $4 / \mathrm{Ag}^{+}$aggregate selectively decreases the viability of cervical carcinoma cells (M-HeLa). In terms of cytotoxic activity, this complex is twice as great as the reference anti-cancer drug imatinib mesylate. Its cytotoxicity against Chang liver cells differs slightly from the known anti-cancer drug. It should be noted that all studied compounds and $3 / \mathrm{Ag}^{+}$aggregates were inactive against MCF-7 and HuTu 80 to cell lines.

Table 1. In vitro cytotoxic effects $(\mu \mathrm{M})$ of sulfobetaine derivatives 3-5 and their aggregates with $\mathrm{Ag}^{+}$.

\begin{tabular}{ccccc}
\hline \multirow{2}{*}{ Test Compounds } & \multicolumn{4}{c}{ IC $_{\mathbf{5 0}}(\boldsymbol{\mu M})$} \\
\cline { 2 - 5 } & M-HeLa & HuTu 80 & MCF-7 & Chang Liver \\
\hline $\mathbf{3}$ & $>5000$ & $>5000$ & $>5000$ & $>5000$ \\
$\mathbf{3} \mathrm{Ag}^{+}$ & $>5000$ & $>5000$ & $>5000$ & $>5000$ \\
$\mathbf{4}$ & $>500$ & $>500$ & $>500$ & $>500$ \\
$\mathbf{5}$ & $\mathbf{3 8 . 9 \pm 2 . 6}$ & $>500$ & $>500$ & $\mathbf{8 5 . 1} \pm \mathbf{6 . 4}$ \\
Imatinib mesylate & $84.7 \pm 6.3$ & $288 \pm 23$ & $207 \pm 17$ & $102 \pm 7.9$ \\
\hline
\end{tabular}

The experiments were repeated for three times. The results are expressed as the mean \pm standard deviation.

The selectivity of compounds for cancer cells is an important criterion for assessing the cytotoxic effect. For this purpose, the selectivity index (SI) was calculated as the ratio between the $\mathrm{IC}_{50}$ value for non-cancer cells and the $\mathrm{IC}_{50}$ for cancer cells. Compounds with SI $\geq 3$ are usually selective [36]. The SI values for lead system $4 / \mathrm{Ag}^{+}$on the $\mathrm{M}-\mathrm{HeLa}$ cell line were 2.2. The reference drug Imatinib mesylate was significantly inferior to the leading compounds in selectivity.

The cytotoxic selectivity of $4 / \mathrm{Ag}^{+}$aggregates may be due to their architecture. It is known from the literature that the shape of nanostructures can have a critical effect on the effectiveness of the cytotoxic action [37]. Indeed, the association of macrocycle 4 in the presence of $\mathrm{Ag}^{+}$leads to the formation of extended nanostructures, while the association of macrocycle 3 with the addition of $\mathrm{AgNO}_{3}$ gives spherical aggregates (Figure 1).

\section{Materials and Methods}

\subsection{General}

All NMR experiments were performed on the Bruker Avance- 400 spectrometer. Chemical shifts were reported relative to deuterated water as an internal standard. Attenuated total internal reflectance, FTIR spectra of all compounds have been recorded using Spectrum 400 (Perkin Elmer) 4000 to $400 \mathrm{~cm}^{-1}$ range. Analysis of elements C, H and $\mathrm{N}$ have been recorded using a Perkin-Elmer $2400 \mathrm{CHN}$ elemental analyzer. MS experiments (electrospray ionization) were carried out using a AmazonX spectrometer (Bruker Daltonics, Bremen, Germany). The ionization parameters were as follows: positive ion mode; capillary voltage $4.5 \mathrm{kV}$, drying gas of $10 \mathrm{~L} / \mathrm{min}$ nitrogen at $300^{\circ} \mathrm{C}$. Mass analyzer scanned from 100 to $2800 \mathrm{u}$. Melting points were determined using the Boetius Block apparatus. Chemicals were purchased from Sigma-Aldrich.

Compounds 1, 2 were synthesized by the authors of $[40,41]$. 


\subsection{General Procedure for the Synthesis of Compounds 3-5}

The compounds 2 (2-cone, 2-paco, 2-alt) $(0.20 \mathrm{~g}, 0.16 \mathrm{mmol})$ and 1,3-propanesultone $(0.64 \mathrm{mmol})$ was mixed in $15 \mathrm{~mL}$ of acetonitrile. The reaction mixture was refluxed for $72 \mathrm{~h}$. After that, solvent was removed under reduced pressure and the residue was dried in vacuo.

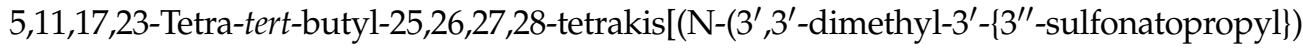
ammoniumpropyl)-carbamoylmethoxy]-2,8,14,20-tetrathiacalix[4]arene (cone) (3) was synthesized in our research group early [32]. Spectral data are presented in Supporting Information (Figures S1-S4).

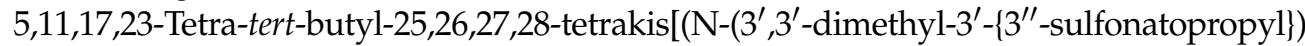
ammoniumpropyl)-carbamoylmethoxy]-2,8,14,20-tetrathiacalix[4]arene (partial cone) (4).

Yield $0.26 \mathrm{~g}(95 \%) .{ }^{1} \mathrm{H}$ NMR (DMSO- $\left.d_{6}, \delta, \mathrm{ppm}, J / \mathrm{Hz}\right): 1.01\left(\mathrm{~s}, 18 \mathrm{H},\left(\mathrm{CH}_{3}\right)_{3} \mathrm{C}\right), 1.28(\mathrm{~s}, 9 \mathrm{H}$, $\left.\left(\mathrm{CH}_{3}\right)_{3} \mathrm{C}\right), \quad 1.29 \quad\left(\mathrm{~s}, \quad 9 \mathrm{H}, \quad\left(\mathrm{CH}_{3}\right)_{3} \mathrm{C}\right), \quad 1.80-2.04 \quad\left(\mathrm{~m}, \quad 16 \mathrm{H}, \quad-\mathrm{N}^{+} \mathrm{CH}_{2} \mathrm{CH}_{2} \mathrm{CH}_{2} \mathrm{SO}_{3}{ }^{-}\right.$, $\left.-\mathrm{NCH}_{2} \mathrm{CH}_{2} \mathrm{CH}_{2} \mathrm{NH}\right), 2.45\left(\mathrm{~m}, 8 \mathrm{H},-\mathrm{N}^{+} \mathrm{CH}_{2} \mathrm{CH}_{2} \mathrm{CH}_{2} \mathrm{SO}_{3}{ }^{-}\right), 2.97-3.03\left(\mathrm{~m}, 24 \mathrm{H},\left(\mathrm{CH}_{3}\right)_{2} \mathrm{~N}^{+}\right), 3.14-$ $3.30\left(\mathrm{~m}, 16 \mathrm{H}, \mathrm{N}^{+} \mathrm{CH}_{2} \mathrm{CH}_{2} \mathrm{CH}_{2} \mathrm{NH},-\mathrm{N}^{+} \mathrm{CH}_{2} \mathrm{CH}_{2} \mathrm{CH}_{2} \mathrm{SO}_{3}{ }^{-}\right), 3.4\left(\mathrm{~m}, 8 \mathrm{H}, \mathrm{N}^{+} \mathrm{CH}_{2} \mathrm{CH}_{2} \mathrm{CH}_{2} \mathrm{NH}\right)$, $4.36\left(\mathrm{~d}, 2 \mathrm{H}, \mathrm{OCH}_{2} \mathrm{CO},{ }^{2} \mathrm{~J}_{\mathrm{HH}}=13.6 \mathrm{~Hz}\right), 4.46\left(\mathrm{~s}, 2 \mathrm{H}, \mathrm{OCH}_{2} \mathrm{CO}\right), 4.54\left(\mathrm{~s}, 2 \mathrm{H}, \mathrm{OCH}_{2} \mathrm{CO}\right)$, $4.82\left(\mathrm{~d}, 2 \mathrm{H}, \mathrm{OCH}_{2} \mathrm{CO},{ }^{2} J_{\mathrm{HH}}=13.6 \mathrm{~Hz}\right), 7.02(\mathrm{~m}, 2 \mathrm{H}, \mathrm{ArH}), 7.64(\mathrm{~m}, 2 \mathrm{H}, \mathrm{ArH}), 7.67(\mathrm{~s}, 2 \mathrm{H}$, $\mathrm{ArH}), 7.76(\mathrm{~s}, 2 \mathrm{H}, \mathrm{ArH}), 8.32(\mathrm{~m}, 2 \mathrm{H}, \mathrm{CONH}), 8.45(\mathrm{~m}, 2 \mathrm{H}, \mathrm{CONH}) .{ }^{13} \mathrm{C}$ NMR (DMSO- $d_{6}$, $\delta$, ppm): 169.21, 168.40, 167.51, 160.02, 157.70, 147.04, 146.08, 135.92, 135.31, 134.44, 128.48, $127.95,127.49,126.92,73.17,63.07,62.67,61.46,61.35,50.49,48.09,36.09,34.45,34.37,34.28$, 31.48, 31.19, 22.76, 22.68, 19.32. FTIR ATR $\left(v, \mathrm{~cm}^{-1}\right): 1663(\mathrm{C}=\mathrm{O}), 2954\left(\mathrm{~N}^{+}\right), 3429(\mathrm{NH})$. El. Anal. Calcd for $\mathrm{C}_{80} \mathrm{H}_{128} \mathrm{~N}_{8} \mathrm{O}_{20} \mathrm{~S}_{8}$ (\%): C $54.03 \%$, H 7.25\%, N 6.30\%, S $14.42 \%$. Found (\%): C $54.47 \%$, H 7.17\%, N 6.57\%, S 14.41\%. MS (ESI): calculated $911.339[\mathrm{M}+2 \mathrm{Na}]^{2+}, 615.222$ $[\mathrm{M}+3 \mathrm{Na}]^{3+}, 607.895[\mathrm{M}+2 \mathrm{Na}+\mathrm{H}]^{3+}$, found: $911.337[\mathrm{M}+2 \mathrm{Na}]^{2+}, 615.221[\mathrm{M}+3 \mathrm{Na}]^{3+}, 607.893$ $[\mathrm{M}+2 \mathrm{Na}+\mathrm{H}]^{3+}$

5,11,17,23-Tetra-tert-butyl-25,26,27,28-tetrakis[(N-(3',3'-dimethyl-3'-\{3'-sulfonatopropyl\}) ammoniumpropyl)-carbamoylmethoxy]-2,8,14,20-tetrathiacalix[4]arene (1,3-alternate) (5).

Yield $0.25 \mathrm{~g}(91 \%) .{ }^{1} \mathrm{H}$ NMR (DMSO- $\left.d_{6}, \delta, \mathrm{ppm}, J / \mathrm{Hz}\right): 1.20\left(\mathrm{~s}, 36 \mathrm{H},\left(\mathrm{CH}_{3}\right)_{3} \mathrm{C}\right), 1.89(\mathrm{~m}$, $\left.8 \mathrm{H}, \quad-\mathrm{NCH}_{2} \mathrm{CH}_{2} \mathrm{CH}_{2} \mathrm{NH}\right), 1.99\left(\mathrm{~m}, 8 \mathrm{H},-\mathrm{N}^{+} \mathrm{CH}_{2} \mathrm{CH}_{2} \mathrm{CH}_{2} \mathrm{SO}_{3}^{-}\right), 2.06 \quad(\mathrm{~m}, 8 \mathrm{H}$, $\left.{ }^{-} \mathrm{N}^{+} \mathrm{CH}_{2} \mathrm{CH}_{2} \mathrm{CH}_{2} \mathrm{SO}_{3}{ }^{-}\right), 3.01\left(\mathrm{~s}, 24 \mathrm{H},\left(\mathrm{CH}_{3}\right)_{2} \mathrm{~N}^{+}\right), 3.18\left(\mathrm{~m}, 8 \mathrm{H},-\mathrm{N}^{+} \mathrm{CH}_{2} \mathrm{CH}_{2} \mathrm{CH}_{2} \mathrm{SO}_{3}{ }^{-}\right), 3.30$ $\left(\mathrm{m}, 8 \mathrm{H}, \mathrm{NCH}_{2} \mathrm{CH}_{2} \mathrm{CH}_{2} \mathrm{NH}\right), 3.43\left(\mathrm{~m}, 8 \mathrm{H}, \mathrm{NCH}_{2} \mathrm{CH}_{2} \mathrm{CH}_{2} \mathrm{NH}\right), 4.01\left(\mathrm{~s}, 8 \mathrm{H}, \mathrm{OCH}_{2} \mathrm{CO}\right), 7.60$ (s, 8H, ArH), $8.06(\mathrm{~m}, 4 \mathrm{H}, \mathrm{CONH}) .{ }^{13} \mathrm{C}$ NMR (DMSO- $\left.d_{6}, \delta, \mathrm{ppm}\right): 167.79,157.64,146.54$, $133.50,127.98,71.54,62.84,61.39,50.52,48.09,39.90,36.19,34.37,31.27,22.84,19.32$. FTIR ATR $\left(v, \mathrm{~cm}^{-1}\right)$ : $1657(\mathrm{C}=\mathrm{O}), 2957\left(\mathrm{~N}^{+}\right) 3300(\mathrm{NH})$. El. Anal. Calcd for $\mathrm{C}_{80} \mathrm{H}_{128} \mathrm{~N}_{8} \mathrm{O}_{20} \mathrm{~S}_{8}$ (\%): C 54.03\%, H 7.25\%, N 6.30\%, S 14.42\%. Found (\%): C 54.36\%, H 7.28\%, N 6.47\%, S 14.40\%. MS (ESI): calculated $1777.7[\mathrm{M}+\mathrm{H}]^{+}, 889.4[\mathrm{M}+2 \mathrm{H}]^{2+}$, found: $1777.6[\mathrm{M}+\mathrm{H}]^{+}, 889.8$ $[\mathrm{M}+2 \mathrm{H}]^{2+}$.

\subsection{Transmission Electron Microscopy (TEM)}

TEM images were obtained using a Hitachi HT7700 Exalens microscope, Japan. The images were acquired at an accelerating voltage of $100 \mathrm{keV}$. Samples were dispersed on 300 mesh copper grids with continuous carbonformvar support films.

\subsection{Dynamic Light Scattering (DLS)}

Hydrodynamic Size of the Particles. Zetasizer Nano ZS instrument (Malvern Instruments, Worcestershire, UK) determined the particle size at $293 \mathrm{~K}$. The source of laser radiation was a He-Ne gas laser with a power of $4 \mathrm{~mW}$ power $\left(\lambda_{\text {operating }}=633 \mathrm{~nm}\right)$. The collected signals were treated in terms of frequency and phase analysis of scattered light using software attached to the device. All measurements were carried out at a $173^{\circ}$ scattering angle. Deionized water with resistivity $>18.0 \mathrm{M} \Omega \mathrm{cm}$ (Millipore-Q) was used for the preparation of the solutions. Synthesized $p$-tert-butylthiacalix[4]arenes 3-5 were dissolved in water at concentrations used in research (from $3 \times 10^{-6} \mathrm{M}$ to $3 \times 10^{-4} \mathrm{M}$ ).

Electrokinetic Potentials. Electrokinetic $(\zeta)$ potentials were determined by electrophoretic light scattering on the Zetasizer Nano ZS (Malvern Instruments, Worcestershire, UK). Sam- 
ples were prepared for the DLS measurements and transferred with the syringe to the disposable folded capillary cell for measurement. The $\zeta$ potentials were measured using the Malvern M3-PALS method and averaged from five measurements.

\subsection{UV-Visible Spectroscopy}

UV-visible spectra were recorded on the Shimadzu UV-3600 spectrophotometer at 293 $\mathrm{K}$. Measurements were carried out in quartz cells with pathway lengths of $1.0 \mathrm{~cm} . \mathrm{AgNO}_{3}$ were used as received. The $1 \times 10^{-4} \mathrm{M}$ solution of the $\mathrm{AgNO}_{3}(300 \mu \mathrm{L})$ in water was added to $0.3 \mathrm{~mL}$ of the solution of host $\left(1 \times 10^{-4} \mathrm{M}\right)$ in water and diluted to final volume of $3 \mathrm{~mL}$ with water.

\subsection{Cytotoxicity Assay}

The M-HeLa clone 11 human, epithelioid cervical carcinoma, strain of HeLa, clone of M-Hela; human duodenal adenocarcinoma (HuTu 80); human breast adenocarcinoma cells (MCF-7) from the Institute of Cytology (Sankt-Petersburg) and human change liver from the collection and Research Institute of Virology, Russian Academy of Medical Sciences (Moscow) were used.

Cell viability was estimated using multifunctional Cytell Cell Imaging system (GE Health Care Life Science, Sweden) and Cell Viability Bio App. The cells were cultured in a standard Eagle's nutrient medium (PanEco) and supplemented with 10\% fetal calf serum and $1 \%$ nonessential amino acids. The cells were seeded in a concentration of $10^{5}$ cells $/ \mathrm{mL}$ in 96-well plates (Eppendorf), then $150 \mu \mathrm{L}$ of standard Eagle's medium (PanEco, Russia) was added per well, and incubation proceeded with $\mathrm{CO}_{2}$ at $37^{\circ} \mathrm{C}$. Twentyfour hours after seeding the cells into wells, the tested compounds were added at a preset dilution, $150 \mu \mathrm{L}$ to each well. Each experiment was repeated three times. Intact cells cultured in parallel with experimental cells were used as a control. The calculation of the concentration of the drug causing inhibition of cell growth by $50 \%$ (IC50) was performed with an Internet tool: MLA- “Quest Graph ${ }^{\mathrm{TM}}$ IC50 Calculator" (AAT Bioquest, Inc., https: / / www.aatbio.com/tools/ic50-calculator, accessed on 25 July 2019).

\section{Conclusions}

Thus, for the first time, we have synthesized a series of water-soluble sulfobetaine derivatives of $p$-tert-butylthiacalix[4]arene in cone, partial cone, and 1,3-alternate conformation. It was shown by dynamic light scattering that none of the synthesized macrocycles 3-5 form stable self-associates in water. The association of macrocycles 3-5 with $\mathrm{Ag}^{+}$was confirmed by DLS methods. The particle size and polydispersity of systems depend on the conformation of macrocycle and are determined by the spatial structure of the sulfobetaine fragments. It was shown by ${ }^{1} \mathrm{H}$ and ${ }^{1} \mathrm{H}_{-}{ }^{1} \mathrm{H}$ NOESY NMR spectroscopy that in the case of cone and 1,3-alternate, intramolecular electrostatic attraction in the sulfobetaine fragment becomes possible, leading to the formation of a stable six-membered ring and coordination of $\mathrm{Ag}^{+}$exclusively over the bridging sulfur atoms and the carbonyl oxygen atoms. In the case of a more conformationally mobile, asymmetric partial cone molecule, such charge compensation turns out to be impossible, and a third coordination center (the terminal sulfo group) appears. This leads to a difference in the morphology of the formed aggregates. In the case of $4 / \mathrm{Ag}^{+}$aggregates, extended nanostructures are formed. The cytotoxic effects are shown to be controlled by the shape of the associates. Among the tested compounds, only the $4 / \mathrm{Ag}^{+}$aggregates act selectively on the cervical carcinoma cell line (M-HeLa). In terms of cytotoxic activity, this complex is two times higher than the reference drug imatinib mesylate. The selective activity against tumor cells in combination with low toxicity toward normal cells allow the consideration of $4 / \mathrm{Ag}^{+}$aggregates as effective novel antitumor agents.

We show structural requirements implicated in the anticancer activity of the thiacalix[4]arene/Ag+ system, which might help to rationalize their development as antitumor agents. We hope that the results of our work will make it possible to develop fundamentally 
new approaches to the synthesis of nanostructures without a drug to solve the problem of multidrug resistance. This work may become the basis for the creation of a new class of anticancer systems: "nano anticancer drugs". The directed design of the structures allows the control of the activity, selectivity, and biological compatibility of nanoparticles exhibiting anticancer properties.

Supplementary Materials: The following are available online, Figures S1, S5 and S9: ${ }^{1} \mathrm{H}$ NMR spectra of the compounds 3-5; Figures S2, S6 and S10: ${ }^{13} \mathrm{C}$ NMR spectra of the compounds 3-5; Figures S3, S7 and S11: Mass spectra of the compounds 3-5; Figures S4, S8 and S12: IR spectra of the compounds 3-5; Figures S13-S42: Size distributions of compounds 3-5 and mixture with $\mathrm{Ag}^{+}$; Figures S43-S45: UV spectra of compounds $3-\mathbf{5}$ with $\mathrm{Ag}^{+}$; Figures S4 and S47: ${ }^{1} \mathrm{H}$ NMR spectrum of the compounds 3 and 5 and their mixtures with $\mathrm{Ag}^{+}$; Figures S48-S53: 2D ${ }^{1} \mathrm{H}-{ }^{1} \mathrm{H}$ NOESY NMR spectra of the compounds 3-5 and their mixtures with $\mathrm{Ag}^{+}$; Tables S1-S4: Size of aggregates formed during association of compound 3-5 and their mixtures with $\mathrm{Ag}^{+}$.

Author Contributions: Conceptualization, writing-review and editing, supervision, I.S.; investigation, writing - original draft preparation, funding acquisition, supervision and visualization, L.Y.; investigation and data curation, A.K., A.N. and P.P.; investigation and software, A.V. and K.P. All authors have read and agreed to the published version of the manuscript.

Funding: The work was supported by Russian Science Foundation (NO. 18-73-10094), https:/ / rscf. $\mathrm{ru} / \mathrm{project} / 18-73-10094 /$.

Institutional Review Board Statement: Not applicable.

Informed Consent Statement: Not applicable.

Data Availability Statement: The data presented in this study are available in Supplementary Materials.

Acknowledgments: The authors are grateful to the staff of the Spectral Analytical Center of Shared Facilities for Study of Structure, Composition and Properties of Substances and Materials of A.E. Arbuzov Institute of Organic and Physical Chemistry of Kazan Scientific Center of Russian Academy of Sciences for their research and assistance in discussing the results. The TEM images were recorded on the equipment of the Interdisciplinary Center for Analytical Microscopy of Kazan Federal University. K.P. and A.V. are grateful to the Ministry of Education and Science of the Russian Federation (theme NO. AAAA-A18-118040390114-8) for financial support in part of cytotoxicity assay.

Conflicts of Interest: The authors declare that they have no known competing financial interests or personal relationships that could appear to have influenced the work reported in this paper.

Sample Availability: Samples of all obtained compounds are available from the authors.

\section{References}

1. Li, J.M.; Wang, Y.Y.; Zhao, M.X.; Tan, C.P.; Li, Y.Q.; Le, X.Y.; Ji, L.N.; Mao, Z.W. Multifunctional QD-based co-delivery of siRNA and doxorubicin to HeLa cells for reversal of multidrug resistance and real-time tracking. Biomaterials 2018, 8, 2780-2790. [CrossRef] [PubMed]

2. Kuo, M.T. Redox Regulation of Multidrug Resistance in Cancer Chemotherapy: Molecular Mechanisms and Therapeutic Opportunities. Antioxid. Redox Signal. 2009, 11, 99-133. [CrossRef] [PubMed]

3. Saraswathy, M.; Gong, S. Different strategies to overcome multidrug resistance in cancer. Biotechnol. Adv. 2013, 31, 1397-1407. [CrossRef] [PubMed]

4. Avner, B.S.; Fialho, A.M.; Chakrabarty, A.M. Overcoming drug resistance in multi-drug resistant cancers and microorganisms. Bioengineered 2012, 3, 262-270. [CrossRef]

5. Flier, J.S.; Underhill, L.H.; Pastan, I.; Gottesman, M. Multiple-Drug Resistance in Human Cancer. N. Engl. J. Med. 1987, 316, 1388-1393. [CrossRef]

6. Mitscher, L.A.; Pillai, S.P.; Gentry, E.J.; Shankel, D.M. Multiple drug resistance. Med. Res. Rev. 1999, 19, 477-496. [CrossRef]

7. Hemaiswarya, S.; Doble, M. Combination of phenylpropanoids with 5-fluorouracil as anti-cancer agents against human cervical cancer (HeLa) cell line. Phytomedicine 2013, 20, 151-158. [CrossRef]

8. Tanwar, J.; Das, S.; Fatima, Z.; Hameed, S. Multidrug Resistance: An Emerging Crisis. Interdiscip. Perspect. Infect. Dis. 2014, 2014, 541340. [CrossRef]

9. Minagawa, Y.; Kigawa, J.; Itamochi, H.; Kanamori, Y.; Shimada, M.; Takahashi, M.; Terakawa, N. Cisplatin-resistant HeLa Cells Are Resistant to Apoptosis via p53-dependent and -independent Pathways. Jpn. J. Cancer Res. 1999, 90, 1373-1379. [CrossRef] 
10. Sameiyan, E.; Hayes, A.W.; Karimi, G. The effect of medicinal plants on multiple drug resistance through autophagy: A review of in vitro studies. Eur. J. Pharmacol. 2019, 852, 244-253. [CrossRef]

11. Medvetz, D.A.; Hindi, K.M.; Panzner, M.J.; Ditto, A.J.; Yun, Y.H.; Youngs, W.J. Anticancer Activity of Ag(I) N-Heterocyclic Carbene Complexes Derived from 4,5-Dichloro-1H-Imidazole. Metal-Based Drugs 2008, 2008, 384010. [CrossRef] [PubMed]

12. World Health Organization (WHO). WHO Consolidated Guidelines on Tuberculosis Module 4: Treatment Drug-Resistant Tuberculosis Treatment; WHO: Geneva, Switzerland, 2020.

13. Eleraky, N.E.; Allam, A.; Hassan, S.B.; Omar, M.M. Nanomedicine fight against antibacterial resistance: An overview of the recent pharmaceutical innovations. Pharmaceutics 2020, 12, 142. [CrossRef]

14. Wang, L.; Hu, C.; Shao, L. The antimicrobial activity of nanoparticles: Present situation and prospects for the future. Int. J. Nanomed. 2017, 12, 1227-1249. [CrossRef] [PubMed]

15. Raja, G.; Jang, Y.K.; Suh, J.S.; Kim, H.S.; Ahn, S.H.; Kim, T.J. Microcellular Environmental Regulation of Silver Nanoparticles in Cancer Therapy: A Critical Review. Cancers 2020, 12, 664. [CrossRef] [PubMed]

16. Padnya, P.; Gorbachuk, V.; Stoikov, I. The Role of Calix[n]arenes and Pillar[n]arenes in the Design of Silver Nanoparticles: Self-Assembly and Application. Int. J. Mol. Sci. 2020, 21, 1425. [CrossRef]

17. Yakimova, L.S.; Gilmanova, L.H.; Evtugyn, V.G.; Osin, Y.N.; Stoikov, I.I. Self-assembled fractal hybrid dendrites from water-soluble anionic (thia)calix[4 ]arenes and $\mathrm{Ag}^{+}$. J. Nanoparticle Res. 2017, 19, 173-183. [CrossRef]

18. Grigoriev, M.; Babich, L. Use of Silver Nanoparticles in Treatment of Socially Significant Diseases. Key Eng. Mater. 2016, 683, 493-499. [CrossRef]

19. Chen, N.; Zheng, Y.; Yin, J.; Li, X.; Zheng, C. Inhibitory effects of silver nanoparticles against adenovirus type 3 in vitro. J. Virol. Methods 2013, 193, 470-477. [CrossRef]

20. Lubick, N. Nanosilver toxicity: Ions, nanoparticles-or both? J. Environ. Sci. Technol. 2008, 42, 8617. [CrossRef]

21. Xu, H.; Qu, F.; Xu, H.; Lai, W.; Wang, A.Y.; Aguilar, Z.P.; Wei, H. Role of reactive oxygen species in the antibacterial mechanism of silver nanoparticles on Escherichia coli O157:H7. BioMetals 2011, 25, 45-53. [CrossRef]

22. Liu, J.; Zhao, Y.; Guo, Q.; Wang, Z.; Wang, H.; Yang, Y.; Huang, Y. TAT-modified nanosilver for combating multidrug-resistant cancer. Biomaterials 2012, 33, 6155-6161. [CrossRef]

23. Cheng, H.B.; Zhang, Y.M.; Liu, Y.; Yoon, J. Turn-On Supramolecular Host-Guest Nanosystems as Theranostics for Cancer. Chem 2019, 5, 553-574. [CrossRef]

24. Vavilova, A.A.; Nosov, R.V.; Yakimova, L.S.; Antipin, I.S.; Stoikov, I.I. Synthesis of Photo-Switchable Derivatives of p-tert-Butyl Thiacalix[4]arenes Containing Ethoxycarbonyl and 4-Amidoazobenzene Fragments in the Lower Rim Substituents. Macroheterocycles 2013, 6, 219-226. [CrossRef]

25. Gorbatchuk, V.V.; Gatiatulin, A.K.; Ziganshin, M.A.; Gubaidullin, A.T.; Yakimova, L.S. Unusually high efficiency of $\beta$-cyclodextrin clathrate preparation by water-free solid-phase guest exchange. J. Phys. Chem. B 2013, 117, 14544-14556. [CrossRef] [PubMed]

26. Puplampu, J.B.; Yakimova, L.S.; Vavilova, A.A.; Fayzullin, D.A.; Zuev, Y.F.; Stoikov, I.I. Synthesis of p-tert-butylthiacalix[4]arenes functionalized with tris(2-aminoethyl)amine fragments at the lower rim and their interaction with model lipid membranes. Macroheterocycles 2014, 7, 337-344. [CrossRef]

27. Gorbatchuk, V.V.; Savelyeva, L.S.; Ziganshin, M.A.; Antipin, I.S.; Sidorov, V.A. Molecular recognition of organic guest vapor by solid adamantylcalix[4]arene. Russ. Chem. Bull. 2004, 53, 60-65. [CrossRef]

28. Kumar, R.; Lee, Y.O.; Bhalla, V.; Kumar, M.; Kim, J.S. Recent developments of thiacalixarene based molecular motifs. Chem. Soc. Rev. 2014, 43, 4824. [CrossRef]

29. Yakimova, L.; Vavilova, A.; Shibaeva, K.; Sultanaev, V.; Mukhametzyanov, T.; Stoikov, I. Supramolecular approaches to the formation of nanostructures based on phosphonate-thiacalix[4]arenes, their selective lysozyme recognition. Colloids Surf. A Physicochem. Eng. 2021, 611, 125897. [CrossRef]

30. Ziganshin, M.A.; Yakimova, L.S.; Khayarov, K.R.; Gorbatchuk, V.V.; Vysotsky, M.O.; Böhmer, V. Guest exchange in dimeric capsules of a tetraurea calix[4]arene in the solid state. Chem. Commun. 2006, 37, 3897-3899. [CrossRef]

31. Yakimova, L.S.; Padnya, P.L.; Kunafina, A.F.; Nugmanova, A.R.; Stoikov, I.I. Sulfobetaine derivatives of thiacalix[4]arene: Synthesis and supramolecular self-assembly of submicron aggregates with AgI cations. Mendeleev Commun. 2019, 29 , 86-88. [CrossRef]

32. Morohashi, N.; Narumi, F.; Iki, N.; Hattori, T.; Miyano, S. Thiacalixarenes. Chem. Rev. 2006, 106, 5291-5316. [CrossRef] [PubMed]

33. Padnya, P.L.; Andreyko, E.A.; Mostovaya, O.A.; Rizvanov, I.K.; Stoikov, I.I. The Synthesis of New Amphiphilic P-TertButylthiacalix[4]Arenes Containing Peptide Fragments and Their Interaction with DNA. Org. Biomol. Chem. 2015, 13, 5894-5904. [CrossRef] [PubMed]

34. Sýkora, J.; Himl, M.; Stibor, I.; Císařová, I.; Lhoták, P. Unique self-assembly patterns based on thiacalix[4]arene-silver interactions Tetrahedron 2007, 63, 2244-2248. [CrossRef]

35. Singh, N.; Kumar, M.; Hundal, G. Synthesis, NMR, X-ray structural analyses and complexation studies of new Ag+ selective calix[4]arene based dipodal hosts-a co-complexation of neutral and charged species. Tetrahedron 2004, 60, 5393-5405. [CrossRef]

36. Ratan, Z.A.; Haidere, M.F.; Nurunnabi, M.; Shahriar, S.M.; Ahammad, A.J.S.; Shim, Y.Y.; Reaney, M.J.T.; Cho, J.Y. Green Chemistry Synthesis of Silver Nanoparticles and Their Potential Anticancer Effects. Cancers 2020, 12, 855. [CrossRef] [PubMed]

37. Vasanth, K.; Ilango, K.; MohanKumar, R.; Agrawal, A.; Dubey, G.P. Anticancer activity of Moringa oleifera mediated silver nanoparticles on human cervical carcinoma cells by apoptosis induction. Colloids Surf. B 2014, 117, 354-359. [CrossRef] 
38. Gurunathan, S.; Han, J.W.; Park, J.H.; Kim, E.S.; Choi, Y.J.; Kwon, D.N.; Kim, J.H. Reduced graphene oxide-silver nanoparticle nanocomposite: A potential anticancer nanotherapy. Int. J. Nanomed. 2015, 10, 6257-6276. [CrossRef]

39. Ayoup, M.S.; Wahby, Y.; Abdel-Hamid, H.; Ramadan, E.S.; Teleb, M.; Abu-Serie, M.M.; Noby, A. Design, synthesis and biological evaluation of novel $\alpha$-acyloxy carboxamides via Passerini reaction as caspase 3/7 activators. Eur. J. Med. Chem. 2019, 168, 340-356. [CrossRef]

40. Andreyko, E.A.; Padnya, P.L.; Daminova, R.R.; Stoikov, I.I. Supramolecular "containers": Self-assembly and functionalization of thiacalix[4]arenes for recognition of amino- and dicarboxylic acids. RSC Adv. 2014, 4, 3556-3565. [CrossRef]

41. Iki, N.; Narumi, F.; Fujimoto, T.; Morohashi, N.; Miyano, S. Selective Synthesis of Three Conformational Isomers of Tetrakis[(Ethoxycarbonyl)Methoxy]Thiacalix[4]Arene and Their Complexation Properties towards Alkali Metal Ions. J. Chem. Soc. Perkin Trans. 2 1998, 2, 2745-2750. [CrossRef] 